\title{
A Study on Determining the Hydropower Potential of Çine Dam in Turkey
}

\author{
Cengiz Koç1*, Yıldırım Bayazıt'², Recep Bakış ${ }^{3^{*}}$ \\ ${ }^{1}$ Department of City and Regional Planning, Faculty of Architecture, Muğla Sıtkı Koçman University, Muğla, \\ Turkey \\ ${ }^{2}$ Department of Civil Engineering, Bilecik Şeyh Edebali University, Bilecik, Turkey \\ ${ }^{3}$ Department of Civil Engineering, Anadolu University, Eskişehir, Turkey \\ Email: "cengizko9@gmail.com, "yildirim.beyazit@bilecik.edu.tr, "rbakis@anadolu.edu.tr
}

Received 28 March 2016; accepted 23 April 2016; published 27 April 2016

Copyright (C) 2016 by authors and Scientific Research Publishing Inc.

This work is licensed under the Creative Commons Attribution International License (CC BY). http://creativecommons.org/licenses/by/4.0/

\section{(c) (i) Open Access}

\section{Abstract}

This study has been conducted with the purpose of determining the hydroelectric potential that can be utilized by Çine dam which will be constructed for irrigation, overflow control and for energy production purposes on the Çine stream (which is located as an important arm of Büyük Menderes River in Turkey). The study will also compare other research conducted by various organizations. In order to determine the hydroelectric energy potential, the SIMAHPP 4 (Simulate and Assess the Feasibility of Hydropower Projects) professional software has been utilized. It has been observed that the calculated hydroelectric potential conforms to energy potential calculated by other organizations such as DSI (State Hydraulic Works). Especially the turbine power, installed power, turbine design flow rate and annual energy production values in the studies have been realized with close values to the real ones. The power plant which is planned to have an average of natural streams of the past 43 years has been designed with an annual power production capacity of $210.87 \mathrm{GWh} /$ year (without regulation ratio) and with installed power of 48,144 MW along with a design flow rate of $35 \mathrm{~m}^{3} / \mathrm{s}$. As a result, since these water structures have high costs associated with them and also since they will have to be functional for many years, it will be beneficial to use various different computational methods.

\section{Keywords}

SIMAHPP, Hydroelectric Potential, Water Sources, Çine Dam, Turkey

\footnotetext{
${ }^{*}$ Corresponding author.
}

How to cite this paper: Koç, C., Bayazıt, Y. and Bakış, R. (2016) A Study on Determining the Hydropower Potential of Çine Dam in Turkey. Computational Water, Energy, and Environmental Engineering, 5, 79-85. 


\section{Introduction}

There is a general view that hydroelectricity is the renewable energy source par excellence as it is non-exhaustible, nonpolluting, and more economically attractive than other options. Hydropower plants emit much less greenhouse gas than thermal plants do. Greenhouse gas emissions of hydropower are caused by the decay of vegetation in flooded areas and by the extensive use of cement in the dam construction. Unfortunately, there are unfavorable local impacts of the use of rivers, social as well as ecological impacts, and they are gaining importance as people become aware of how those impacts affect living standards. On the other hand, most renewable sources of energy (such as hydroelectricity generation) are capital intensive, but have lower operational cost than thermal and nuclear options. The high initial cost is a serious barrier for its growth in developing countries, where most of the untapped economic potential is located.

Hydropower is available in a broad range of project scales and types. Projects can be designed to suit particular needs and specific site conditions. Since hydropower does not consume or pollute the water that it uses to generate power, it leaves this vital resource available for other uses. At the same time, the revenues generated through electricity sales can finance other infrastructure essential for human welfare. This can include drinking water supply systems, irrigation schemes for food production, infrastructures enhancing navigation, recreational facilities and ecotourism [1]-[4].

Turkey has a gross annual hydro potential of $433,000 \mathrm{GWh}$, which is almost $1 \%$ of the world's total potential. Of the total hydropower capacity in Europe, Turkey's share is about $14 \%$. Almost half of the gross potential is technically exploitable, and $28 \%(122,322 \mathrm{GWh} /$ year $)$ is economically exploitable [5]. As of November 2000, there were 120 hydro plants in operation. These have a total installed capacity of 11,588 MW and an annual average generation capacity of $42,015 \mathrm{GWh}$, amounting to almost $34 \%$ of the total exploitable potential, which is at present meeting about $35 \%$ of the electricity demand. Thirty-four hydro plants with an installed capacity of $3305 \mathrm{MW}$ and an annual generation capacity of 10,981 GWh, which is almost $9 \%$ of the total potential, are under construction. The hydroelectric energy established power has shown an increase over the years. In the 1970s, it was $725 \mathrm{MW}$, in 2005 12,906 MW and it was 15,831.20 MW in 2010. Of the 281 hydroelectric power plants in Turkey under operation, 13,318.9 MW (79\%) of them are of dam-type power plants and 3607.9 MW (21\%) are river-run type power plants for the years 2002-2012 [6].

This study has been conducted with the purpose of determining the hydroelectric potential that can be utilized by Çine dam which will be constructed for irrigation, flood control and for energy production on the Çine stream in Turkey. The study will also compare other research conducted by various organizations.

\section{Material and Method}

\subsection{Material}

The study area is located in the Çine sub-basin of the Büyük Menderes River in western Anatolia (Figure 1). The stream of Çine, which is a part of Büyük Menderes River, is the water source of the area. The length of Çine stream is $105 \mathrm{~km}$ and the precipitation area is $1418 \mathrm{~km}^{2}$. The study area shows features of the Mediterranean climate. The average annual rainfall varies from $600-1100 \mathrm{~mm}$. The average annual temperature is around $17^{\circ} \mathrm{C}$. The annual net evaporation is recorded as $835 \mathrm{~mm}$. 43-year average natural flow over the point where the dam has been built is $380.36 \times 106 \mathrm{~m}^{3} /$ year. The amount of water that can be withdrawn from the dam for power generation is planned as $194.02 \times 106 \mathrm{~m}^{3} /$ year. The regulation ratio is $51 \%$ which is the ratio of the amount of water used for energy production to the total expected water amount. The project area water quality is $\mathrm{C}_{2} \mathrm{~S}_{1}$. The Çine dam is built as Roller Compacted Concrete type, and it has been planned for irrigation, flood control and hydropower production. The information about Çine Dam in the project area as well as information about the hydropower plant planning is provided in Table 1.

\subsection{Method}

In this study, the preliminary feasibility analysis of the hydroelectric energy potential of Çine Dam has been conducted with SIMAHPP (Simulate and Assess the Feasibility of Hydropower Projects) 4 Software. SIMAHPP4 Professional is proprietary Windows operating system based program which is utilized to simulate and assess the feasibility of hydropower projects by using hydraulic, financial, and environmental parameters. SIMAHPP has been used internationally by consultants, university professors, researchers, and turbine manufacturers to analyze 


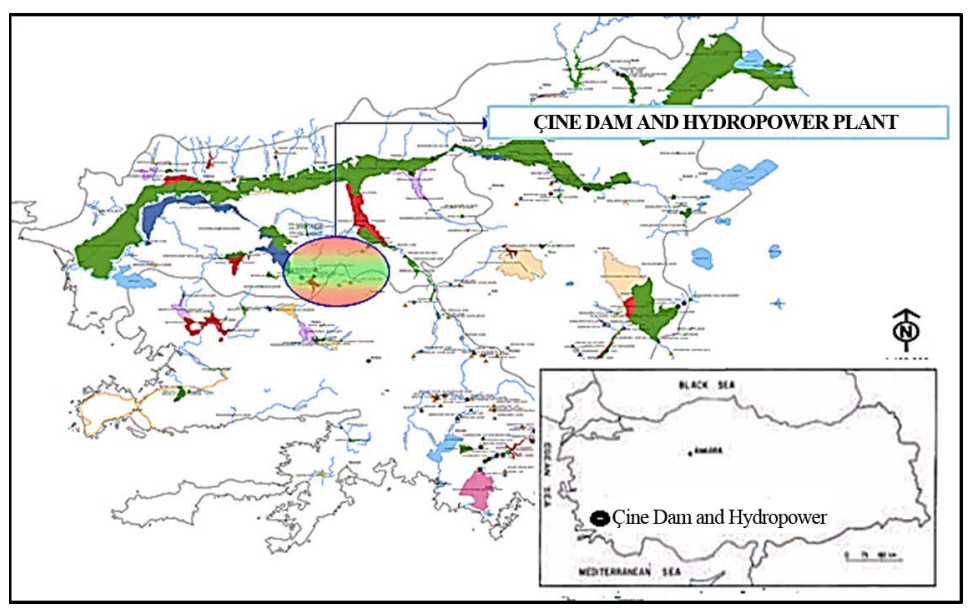

Figure 1. Location of Çine dam constructed and hydroelectric power plant planned in Turkey.

Table 1. Characteristics of Çine dam and hydroelectric power plant planned [7].

\begin{tabular}{|c|c|c|c|}
\hline \multicolumn{2}{|l|}{ Çine dam } & \multicolumn{2}{|c|}{ Çine hydroelectric power plant } \\
\hline Maximum flood discharge & $3578 \mathrm{~m}^{3} / \mathrm{s}$ & Maximum fall & $147.60 \mathrm{~m}$ \\
\hline Shifted maximum flood & $2570 \mathrm{~m}^{3} / \mathrm{s}$ & Normal fall & $146.30 \mathrm{~m}$ \\
\hline Storage volume at crest level & $350 \times 10^{6} \mathrm{~m}^{3}$ & Minimum fall & $97.30 \mathrm{~m}$ \\
\hline Lake surface area at crest level & $9.34 \mathrm{~km}^{2}$ & Power tunnel length & $2555.00 \mathrm{~m}$ \\
\hline Dam type & weight RCC & Power tunnel diameter & $3.90 \mathrm{~m}$ \\
\hline Dam height from thalweg & $130.00 \mathrm{~m}$ & Penstock diameter & $3.90-3.20 \mathrm{~m}$ \\
\hline Crest Length & $300.00 \mathrm{~m}$ & Penstock length & $291.62 \mathrm{~m}$ \\
\hline Crest wide & $150.00 \mathrm{~m}$ & Power tunnel sill level & $195.26 \mathrm{~m}$ \\
\hline Spillway type & stepped & Tail-water level & $107.50 \mathrm{~m}$ \\
\hline Spillway capacity & $2578 \mathrm{~m}^{3} / \mathrm{s}$ & Average discharge & $12.061 \mathrm{~m}^{3} / \mathrm{s}$ \\
\hline Maximum water level (in Flood) & $264.80 \mathrm{~m}$ & Regulation rate & $51 \%$ \\
\hline Normal water level & $260.00 \mathrm{~m}$ & Amount of water energized & $194.02 \times 10^{6} \mathrm{~m}^{3}$ \\
\hline Minimum water level & $205.00 \mathrm{~m}$ & & \\
\hline
\end{tabular}

hydropower potential. SIMAHPP Professional is a multi-site, multi-option simulator intended to solve a wide range of problems such as determining design flows and to select suitable hydro-turbines, optimize time of operation in a year so as to maximize annual energy production, determine the energy revenue, estimate investment and maintenance costs, determine amortization rates, Net Present Value (NPV), Internal Rate of Return (IRR), payback periods, and indicates the impact of the project on reducing carbon emission reduction as well as the potential for carbon market revenue if the planned hydropower project is to be operational (www.hydroxpert.com) The software can be inputted with multiple Hydroelectric plant projects. For complete analysis, 3 different types of data input are required. These parameters are hydraulic, financial and environmental parameters (Figure 2). During the data input for hydraulic parameter, average flow value for one of the daily, monthly or annual flow rates have to be entered. If daily flow rate value is to be inputted, then 365 values are required, but if monthly flow values are to be inputted then only 12 flow values are needed. Since the annual flow rate for Çine stream was calculated in this study, only a single flow value has been entered into the software. Furthermore, in this section, the height where the water will fall is given in meters. Then following those the required financial data is entered. In this section, data such as investment costs, annual or monthly depreciation plan and 


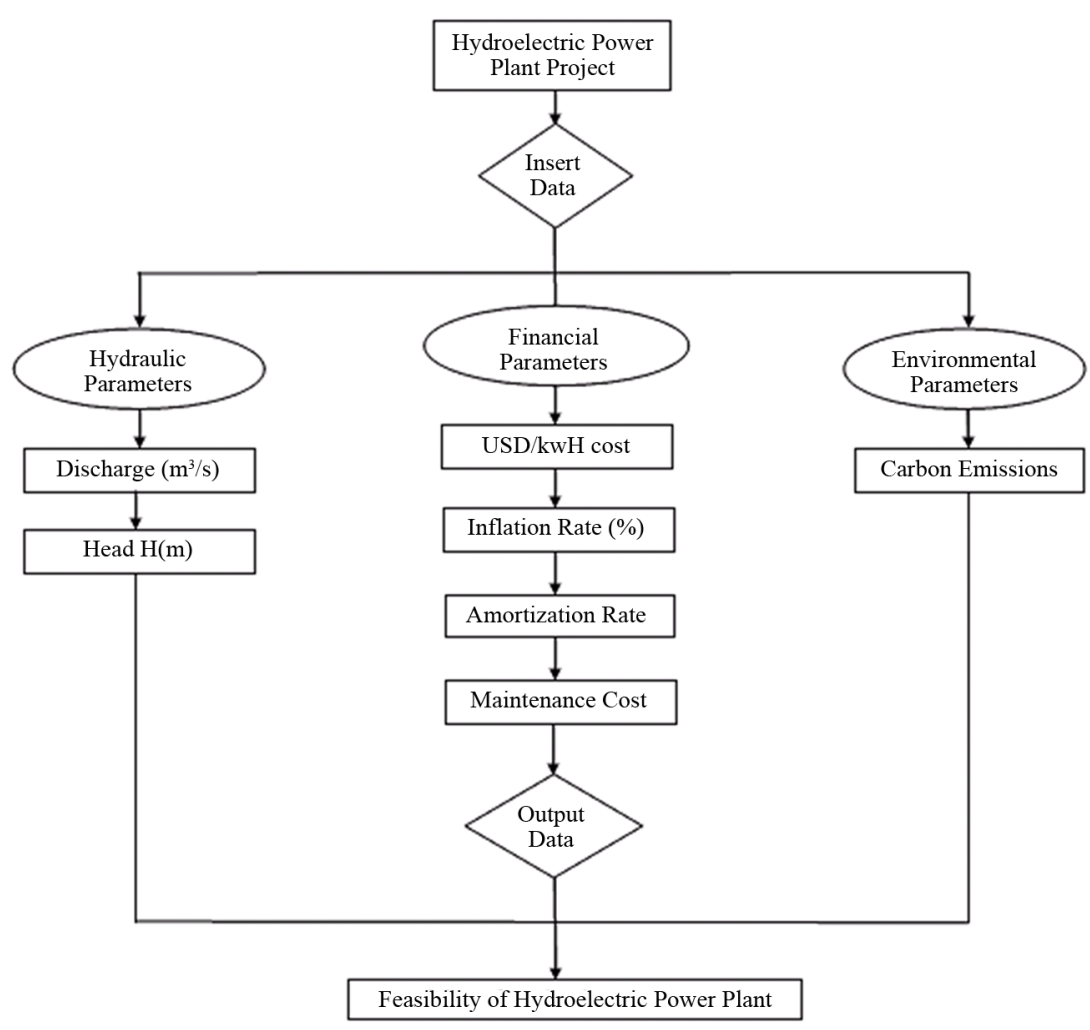

Figure 2. Flow diagram SIMAHPP 4 Professional package program.

carbon market values are entered. Lastly, in the section for the environmental parameters, the carbon emission rates are inputted for the calculation of carbon emission reduction potential for hydroelectric energy as compared to other sources. Once these data are entered then the analysis is completed. The results are then given as plots and as tables [8].

\section{Results and Discussion}

In this study, the potential of Cine hydropower dam is calculated using SIMAHPP 4 Professional software and the DSI Çine dam hydroelectric power plant (HPP) on the same dam is compared with planning data. The amount of electricity to be generated by the dam of the year in Çine, installed capacity, turbine design flow, power production, energy production, investment and self-calculated data, such as payback period is given in Table 2. The graphics for the software results were plotted in Figure 3. Results that examined HPP costs totaling $49.6 \times 10^{6}$ EUR is the amount of electricity to be produced annually $210.87 \mathrm{GWh} /$ year (regulation disproportionate) total installed capacity of $48.144 \mathrm{MW}$ turbine design flow rate of $35 \mathrm{~m}^{3} / \mathrm{s}$, the monetary value of the annual energy $22 \times 106 \mathrm{EUR}$, per kWh investment the price of $1030.755 \mathrm{EUR} /$ person and the payback period is estimated to be 2235 years.

When the power-probability chart is examined, it is observed that the curve is parallel to the flow continuity plot. As flow rate grows, the power produced will increase, while decreasing the flow reduces the power. However, the data entered to the software is the average annual flow rate. Therefore, calculations are made assuming that there is constant flow happening for 12 months. Thus, this is why flow-continuity and power-probability plots are coming out as constants. When the chart for energy production is analyzed it has constant energy increase as the flow is constant for 12 months. On the other hand, emission reduction results which appear in software $\left[\left(\mathrm{CO}_{2} /\right.\right.$ year)-Coal $\left(\mathrm{CO}_{2} /\right.$ year)-Gas $\left(\mathrm{CO}_{2} /\right.$ year)-fuel (or oil)] are closely related to the carbon markets. The carbon market is a market to sell and buy shares of greenhouse gases in order for countries to reach their emission targets.

In 1997, this market has come up with a meeting in Kyoto, and 39 developed countries have agreed to make the amount of carbon emissions in the atmosphere reduce down to levels to below 5\% as per 1990 emission levels. 

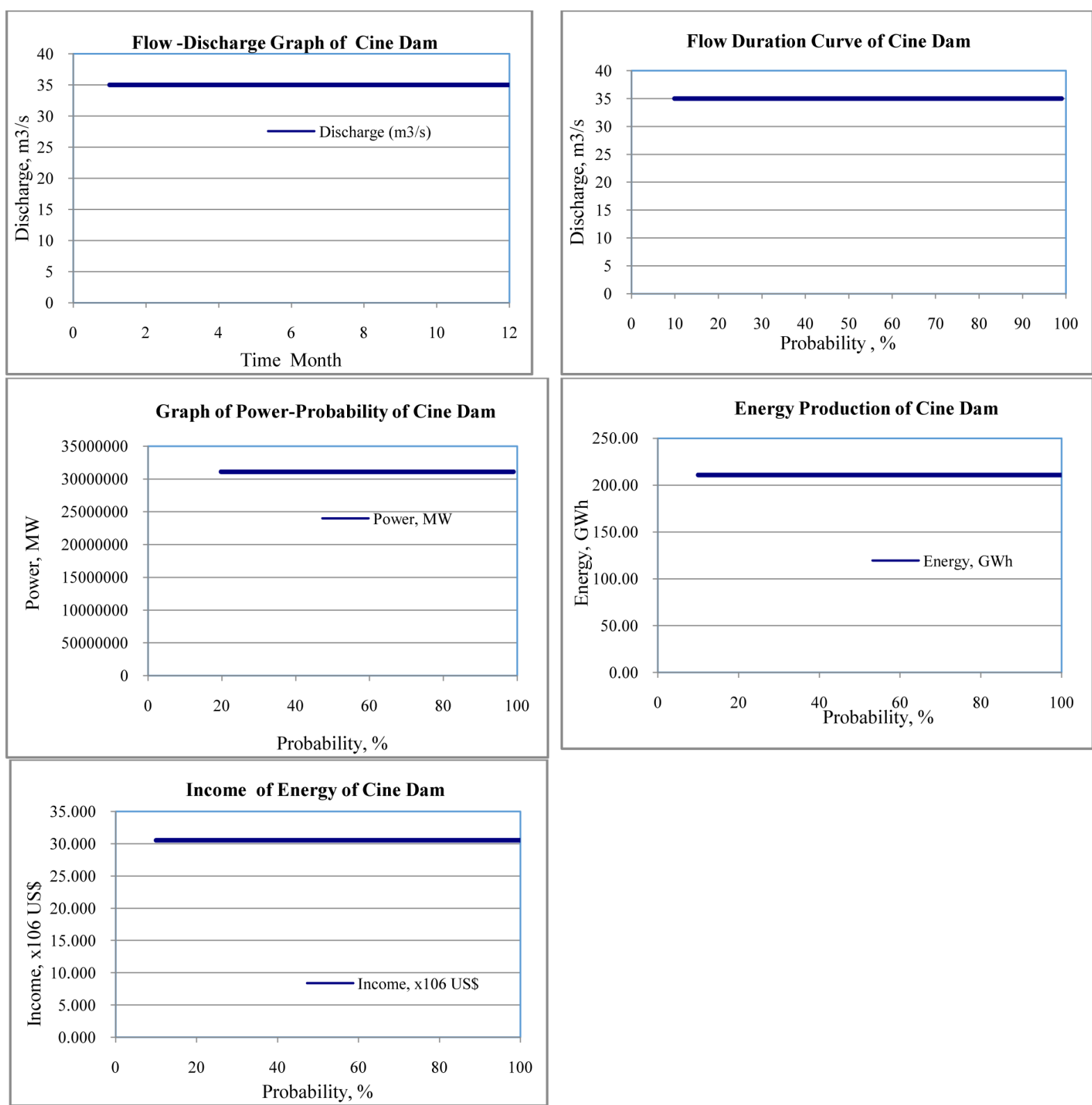

Figure 3. Graphics of flow-discharge, flow duration, power, energy production, and energy income of Çine dam hydroelectric plant.

The Kyoto Protocol limits the carbon emissions quotas for each country and industry. According to this protocol, each member country has been allocated a certain quota of carbon. Each country will allocate this quota among its industrialists. If any producer or country exceeds its quota, it will compensate for the error by purchasing carbon quota from others that produce less carbon. In other words, companies and states that cause air pollution (those causing the release of more carbon emissions into the atmosphere) will be giving money to those with less carbon emissions in order to provide the balance. This form of greenhouse gas emissions will remain constant throughout the world. The European Union Emission Trading System (2003/87/EC, EUETS- European Union Emission Trading Scheme) covers 25 countries and 13,000 organizations since 2005. Since 2005 , 362 million tons of $\mathrm{CO}_{2}$ have seen monetary value of the total transactions and it has reached 7.2 billion Euros. As of 2012, trillion dollars of trade volume is reported [9] [10]. Accordingly, in the studies, it is observed that in order to produce $210.87 \mathrm{GWh}$ /year power, the amount of coal needed to generate this electricity in a year will lead to $126,523.843$ tons of $\mathrm{CO}_{2}$ emissions into the atmosphere. If gas is used then $42,174.614$ tons of $\mathrm{CO}_{2}$ emissions are 
Table 2. Hydroelectric project characteristics calculated by the method SIMAHPP 4 professional.

\begin{tabular}{cc}
\hline Project characteristics & Option 1 \\
Net head (m) & 147.600 \\
Design flow (m/s) & 35.000 \\
Design time of operation (\%) & 100.000 \\
Power production (kW) & $48,144.537$ \\
Energy production (kWh/year) & $210,873,072,060.000$ \\
Energy revenue (EUR/year) & $22,795,379,090.000$ \\
Emission reduction (tCO $/$ year-Coal) & $126,523,843.000$ \\
Emission reduction (tCO $/$ year-Gas) & $42,174.614$ \\
Emission reduction (tCO $/$ year-Fuel) & $67,479.383$ \\
Carbon market (EUR/year)-Mean & $787,259.467$ \\
Investment cost (EUR) & $49,625,200.139$ \\
Investment cost /kW (EUR/kW) & 1030.755 \\
Investment cost/kWh (EUR/kWh) & 0.235 \\
O \& M Cost (EUR/year) & $595,502.402$ \\
NVP: Net Present Value (EUR) & $606,777,525.321$ \\
IRR: Internal Rate of Return (\%) & 46.000 \\
Payback period (Years) & 2.235 \\
Amortization plan (Yearly) & $1,787,867.910$ \\
Suggested turbine type & Pelton/Turgo \\
Exchange rate (31.12.2015), 1 EUR & 1.000000 EUR \\
\hline & \\
\hline & \\
\hline
\end{tabular}

released and when oil is used, it causes 67479.383 tons of $\mathrm{CO}_{2}$ to be released into the atmosphere. The value of these oscillations of the carbon market will be 787,259,467 EUR per year. Therefore, a hydroelectric power has environmental features and thus offers an important contribution for reducing global warming.

The DSI data and the hydroelectric potential determined through the software for Çine dam is given in Table 3. As per this table, $147.6 \mathrm{~m}$ water fall height is found, and the amount of electricity it will produce is $118 \mathrm{GWh}$ per annum with an installed capacity of 47.2 MW with a Francis turbine type having a vertical axis [11]. The calculations made by computer software has determined the turbine design flow rate as $35 \mathrm{~m}^{3} / \mathrm{h}$, the amount of energy that can be produced per year with a height of $147.6 \mathrm{~m}$ is found to be $107.54 \mathrm{GWh}(210.87 \times 0.51)$, and turbine power installed capacity is determined to be $48.14 \mathrm{MW}$. When the results obtained from studies of the parameters are examined, it is observed that there are some minor differences with the parameters set by DSI. The overlap rate of parameters obtained from two studies ranges from 0.98 to 1.09 . The differences are seen only in the selection of the turbine type and number of installed units. Since Francis type turbines are being used in power plants in the recent years, this has also been the selection for this study. During the software calculation, a single turbine unit has been considered. The reason for determining 2 as the number of turbines by DSI is due to the fact that it will also be used for irrigation. Irrigation water demand will vary throughout the season and in order to get the energy of the water flow it is a good idea to use 2 turbines. This selection will provide significant flexibility for operability of dams which are used for irrigation and power production.

\section{Conclusions and Recommendations}

The parameter values calculated through the software have been compared with the planning parameters of the hydroelectric energy potential of Çine dam constructed by a public organization (DSI). As a result, even though different calculation methods have been used in the 2 studies, still data values close to each other have been obtained. In these types of planning, it is possible to use different calculation methods to create the most suitable 
Table 3. Parameters calculated in the research area and planned by the DSI.

\begin{tabular}{cccc}
\hline & \multicolumn{2}{c}{ Parameters } \\
\hline & DSI planning & Calculated for research area & Overlap ratio \\
\hline Number of units & 2 & 1 & - \\
Installed power & $47.20 \mathrm{MW}$ & $48.14 \mathrm{MW}$ & 0.98 \\
Turbine power & $23.60 \mathrm{MW} \times 2$ & $48.14 \mathrm{MW}$ & - \\
Turbine type & Francis (vertical axis) & Pelton or Turgo Türbine & 1.09 \\
Energy production & $118 \mathrm{GWh} /$ year & $107.54 \mathrm{GWh} /$ year $(210.87 \times 0.51)$ & 1.00 \\
Net fall & $147.60 \mathrm{~m}$ & $147.6 \mathrm{~m}$ & 1.00 \\
Design discharge & $35 \mathrm{~m}^{3} / \mathrm{s}(17.50 \times 2)$ & $35 \mathrm{~m}^{3} / \mathrm{s}$ & \\
\hline
\end{tabular}

and economical solution. Especially before developing energy projects it is important to work in a detailed and meticulous manner during the planning stage. This is especially important for water structures, since they are structures designed to give longer term service and have high costs and thus calculation errors during the planning stage can cause problems which can't be eradicated at later stages. During the calculation of the hydroelectric potential, it is especially crucial to determine the flow rate of the water source and the net decrease in heights. It will be possible to create highly efficient energy projects by evaluating the data with different calculation methods and then comparing the results.

\section{References}

[1] Kaygusuz, K. (2002) Sustainable Development of Hydropower. Energy Sources, 24, 803-815.

[2] Kaygusuz, K. (2004) Hydropower and World’s Energy Future. Energy Sources, 26, 215-224. http://dx.doi.org/10.1080/00908310490256572

[3] Yüksel, I. (2008) Global Warming and Renewable Energy Sources for Sustainable Development in Turkey. Renewable Energy, 33, 802-812. http://dx.doi.org/10.1016/j.renene.2007.05.040

[4] Yüksel, I. (2010) Hydropower for Sustainable Water and Energy Development. Renewable and Sustainable Energy Reviews, 14, 462-469. http://dx.doi.org/10.1016/j.rser.2009.07.025

[5] DSI (State Hydraulic Works) (2012) Hydroelectric Power Potential of Turkey. General Directorate of State Hydraulic Works (DSI), Ministry of Forestry and Hydraulic Works, Ankara. www.dsi.gov.tr

[6] Koç, C. (2014) A Study on the Development of Hydropower Potential in Turkey. Renewable and Sustainable Energy Reviews, 39, 498-508.

[7] DSI (State Hydraulic Works) (2001) Planning Report of Çine Dam and Hydroelectric Power Plant. General Directorate of State Hydraulic Works (DSI), Ministry of Forestry and Hydraulic Works, 21. Rural Directorate of State Hydraulic Works, Aydın. Report No: 1240, 350 p.

[8] Hydroxpert Technology-Energy, Water, Environment, Infrastructure; SIMAHPP 4 Professional Packet Program. http://www.hydroexpert.com/

[9] Taşdan, F. (2009) Karbon Piyasası, Türkiye Teknik Elemanlar Vakfi. Enerji Bülteni, Y11 1, Say1 7.

[10] Yorkan, A. (2009) Avrupa Birliği’nin Enerji Politikası Ve Türkiye’ye Etkileri. Bilge Strateji, Cilt 1, Say1 1, $24-39$.

[11] DSI (State Hydraulic Works) (2014) Revise Planning Report of Çine Dam and Hydroelectric Power Plant. General Directorate of State Hydraulic Works (DSI), Ministry of Forestry and Hydraulic Works, 21. Rural Directorate of State Hydraulic Works. Aydın. Report No: 1534, 156 p. 